\title{
UPLC-ESI/MS/MS Profiling and Anti-Inflammatory Activity of Gleditsia caspica
}

\author{
Hagar Ashraf ${ }^{\text {a }}$, Ashaimaa Y. Moussa ${ }^{\text {a }}$, Amany A. Seleem ${ }^{\text {b }}$, Omayma A. Eldahshan ${ }^{\text {a,c }}$, Abdel Nasser B. Singab ${ }^{\text {*a,c }}$ \\ ${ }^{a}$ Department of Pharmacognosy, Faculty of Pharmacy, Ain Shams University, Cairo 11566, Egypt \\ ${ }^{\mathrm{b}}$ Department of Toxicology and Narcotics National Research Center, Cairo, Egypt \\ ${ }^{\mathrm{c}}$ Drug Discovery Center Research and Development, Faculty of Pharmacy, Ain Shams University, Cairo 11566, \\ Egypt
}

\begin{abstract}
The Caspian Locust is the common name of Gleditsia caspica, a tree cultivated in the southern and western Caspian Sea in Russia and Iran. Herein, a qualitative characterization of the chemical constituents of Gleditsia caspica leaves extract using ultra-performance liquid chromatography coupled to electrospray ionization tandem mass fragmentation (UPLC-ESI/MS/MS) analysis was performed revealing the presence of nine compounds: six flavonoids, one triterpenoid, one phytosterol, and one long chain ester. Six compounds were newly reported from Gleditsia caspica and two for the first time from genus Gleditsia. Moreover, the in-vivo anti-inflammatory activities of two different doses; 50 and 100 $\mathrm{mg} / \mathrm{kg}$ of the aqueous-alcoholic extract of Gleditsia caspica leaves were evaluated in the carrageenaninduced paw edema model. The percentage of edema inhibition was calculated after 1, 2, 3, and $4 \mathrm{~h}$ of the administration showing a significant reduction in edema thickness in a dose and time-dependent manner compared to the control drug, indomethacin. These results put forward Gleditsia caspica extract as a potential natural anti-inflammatory agent with minimal side effects.
\end{abstract}

Keywords: Gleditsia caspica; flavonoids; Fabaceae; glycosides; inflammation.

*Correspondence | Abdel Nasser B. Singab; Department of Pharmacognosy, Faculty of Pharmacy, Ain Shams University, Cairo 11566, Egypt. Email: dean@pharma.asu.edu.eg

Citation | Ashraf H, Moussa A Y, Seleem AA, Eldahshan OA, Singab AB, 2020. UPLC-ESI/MS/MS Profiling and Anti-Inflammatory Activity of Gleditsia caspica. Arch Pharm Sci ASU 4(1): 124-134

DOI: $10.21608 /$ APS.2020.2004.1042

Print ISSN: 2356-8380. Online ISSN: 2356-8399.

Received 01 April 2020. Accepted 31 May 2020.

Copyright: ${ }^{\circledR} 2020$ Ashraf et al. This is an open-access article licensed under a Creative Commons Attribution 4.0 International License (CC BY 4.0), which permits unrestricted use, distribution, and reproduction in any medium, provided the original author(s) and source are credited.

Published by: Ain Shams University, Faculty of Pharmacy

\section{INTRODUCTION}

Gleditsia caspica Desf. (Caspian Locust), subfamily Caesalpinioideae, is one of fourteen species belonging to family Fabaceae. Genus Gleditsia has been widely used in traditional medicine since 2000 years ago [1]. The majority of Gleditsia species diversity is found in Eastern Asia, Southern Caucasus, North, and South America [2] where they have been used in treating productive cough, asthma, suppuration, headache, apoplexy, carbuncle, swelling, and scabies. While phytochemical studies revealed the presence of sterols [3], triterpenes [3-5], phenolics [6, 7], alkaloids [8, 9] and saponins $[10,11]$ as the most characteristic constituents of the fruits and thorns, Gleditsia triacanthos was the only species whose leaves were studied and revealed the presence of flavonoids and the alkaloid triacanthine $[8,12,13]$. 
The fruit extract of Gleditsia caspica revealed the presence of eleven novel saponins (caspicaoside A-K) and three oleanane type triterpenoidal saponins (caspicaoside L-N) [1416]. Saponins isolated from Gleditsia caspica fruit extract (caspicaoside A-D) and (caspicaoside L-N) were reported to exhibit various cytotoxic activities on different cancer cell lines [14]; moreover, they were proved to possess anti-mutagenic activity [17]. Accordingly, there is a vacancy of information regarding the chemical constituents of the Gleditsia leaves and their biological activity. Genus Gleditsia possessed a variety of biological activities such as anti-inflammatory [18], cytotoxic [19-21], antiallergic [22, 23], antihyperlipidemic [24], analgesic [25], antimicrobial $[6,26]$, antioxidant $[8,12,13]$ and antimutagenic activities [3, 17], yet few studies tested the in-vivo bioactivity against inflammation [18, 22, 27, 28].

More than $70 \%$ of the anti-inflammatory drugs are synthetic despite having potentially adverse effects [29]. Non-steroidal antiinflammatory drugs (NSAIDS) as salicylates, pyrazolones, indole derivatives, and quinolone derivatives are the most widely used antiinflammatory molecules [30]. Recently, many NSAIDs have been used as topical preparations in the treatment of some inflammatory disorders. Photoallergic contact dermatitis has been reported from propionic acid derivatives and photosensitivity from piroxicam [31, 32]. Moreover, contact urticaria has been reported from oxyphenbutazone [33]. On the other hand, topical anti-inflammatory synthetic corticosteroids possess a variety of adverse effects such as skin atrophy and telangiectasia, that's why long-term use of topical steroids is limited [34]. Topical synthetic retinoids are a class of anti-inflammatory drugs used mainly in acne treatment and can lead to toxic contact dermatitis [35].

Medicinal herbs have great potential to act as therapeutic agents against inflammation mainly because of their antioxidant and cytoprotective properties [36-38]. Biological investigations of Gleditsia species revealed that both thorns and fruits extracts of Gleditsia sinensis possessed anti-inflammatory activities with different mechanisms of actions [18, 22, 27, 28]. Herein, we aimed to characterize for the first time the chemical profile of Gleditsia caspica leaves using UPLC-ESI/MS/MS; moreover, the in-vivo anti-inflammatory activity in carrageenaninduced paw edema model was probed to present a potential new natural topical anti-inflammatory agent with the least side effects.

\section{MATERIALS AND METHODS}

\subsection{Plant material}

Fresh leaves of Gleditsia caspica (Fabaceae) were collected from the plant growing in ElOrman botanical garden, Ministry of Agriculture, Giza, in December (2016). They were kindly authenticated by Ms. Therese Labib, a botanical specialist and consultant at Orman and Qubba Botanical Gardens. A voucher specimen of the authenticated plant was deposited at the Department of Pharmacognosy, Faculty of Pharmacy, Ain Shams University under the registration code (PHG-P-GC-212).

\subsection{Extract preparation}

The intact air-dried plant material was ground into powder, macerated in distilled methanol $70 \%$ for 3 days, and filtered. The process was repeated four times before the hydro-alcoholic extract was concentrated using a rotary evaporator. The filtrate was completely evaporated in vacuo at 45 ${ }^{\circ} \mathrm{C}$ till dryness to yield a solid dark brown residue (250 g). 


\subsection{UPLC-ESI/MS/MS profiling}

Ultra-performance liquid chromatographic (UPLC) analysis coupled with an ESI mass spectrometer detector allowed simultaneous isolation of the compounds and determination of the isolated peaks molecular weights. Samples $(100 \mu \mathrm{g} / \mathrm{mL})$ were dissolved in high-performance liquid chromatography (HPLC) analytical grade methanol, filtered using a membrane disc filter $(0.2 \mu \mathrm{m})$, and subjected to UPLC-ESI-MS/MS analysis. Samples $(10 \mu \mathrm{L})$ were injected into the UPLC instrument, Waters ${ }^{\circledR}$ equipped with a reversed-phase C-18 column (ACQUITY UPLC BEH C18 $1.7 \mu \mathrm{m}$ particle size $-2.1 \times 50 \mathrm{~mm})$. The mobile phase was filtered using a $0.2 \mu \mathrm{m}$ membrane disc filter and sonicated before injection. The Elution flow rate was adjusted to $0.2 \mathrm{~mL} / \mathrm{min}$; the gradient was composed of two eluents: water acidified with $0.1 \%$ formic acid and methanol acidified with $0.1 \%$ formic acid. Both negative and positive ion modes were used on a triquadrupole (XEVO) mass spectrometry, Waters ${ }^{\circledR}$ Corporation, Milford, MA01757 U.S.A. $30 \mathrm{eV}$ cone voltage, $3 \mathrm{kV}$ capillary voltage at 150 ${ }^{\circ} \mathrm{C}, 440{ }^{\circ} \mathrm{C}$ desolvation temperature were applied. Detection of mass spectra was in the ESI range $m / z$ 100-1000 using the software Maslynx 4.1 and tentatively identified by comparing the retention time (Rt) peaks in the mass spectrum and their fragmentation pattern with reported data.

\subsection{In-vivo anti-inflammatory evaluation}

The anti-inflammatory activity of the hydro-alcoholic extract of Gleditsia caspica leaves was evaluated in the carrageenan-induced paw edema model according to the method described before [39]. Twenty four adult male albino rats, weighing between 130-150 g were maintained under normal laboratory conditions at room temperature of $25-30{ }^{\circ} \mathrm{C}, 60-65 \%$ relative humidity, and provided with standard diet and water. The study was conducted according to regulations of the Institutional Animal Ethical Committee of the National Research Centre which gave its consent following the National Regulations on Animal Welfare and Institutional Animal Ethical Committee (registration no. 90123) [40]. Four groups, each of six animals, were treated as follow: group I: received $1 \mathrm{~mL}$ of saline serving as control, group II: received 50 $\mathrm{mg} / \mathrm{kg}$ of the Gleditsia caspica extract, group III: received $100 \mathrm{mg} / \mathrm{kg}$ of the Gleditsia caspica extract, and group IV: received $20 \mathrm{mg} / \mathrm{kg}$ of the reference indomethacin. One hour later, paw swelling was induced by sub plantar injection of $0.1 \mathrm{~mL}$ of $1 \%$ carrageenan solution in saline into the right hind paw of all groups. The edema thickness was calculated by measuring the hind paw thickness immediately before sub plantar injection and at $1,2,3$, and $4 \mathrm{~h}$ after drug administration. The percentage of inhibitory activity at each time point was calculated according to the following equation [41].

Percent of inhibition $=\mathrm{X}-\mathrm{Y} / \mathrm{X} \times 100$

Where " $X$ " represents the animal's paw diameter in the control group and "Y" represents the diameter of the animal's paw administered with the tested materials.

\subsection{Statistical analysis}

Anti-inflammatory data were expressed as mean \pm standard deviation and statistical analysis was performed using the one-way analysis of variance (ANOVA), followed by posthoc Tukey's test for multiple comparisons. Values with $\mathrm{P}<0.05$ were considered statistically significant.

\section{RESULTS}

\subsection{Metabolites profiling of Gleditsia caspica extract}

This study aimed to characterize the Phytoconstituents (Table 1) within the bioactive Gleditsia caspica extract using the UPLCESI/MS/MS approach, which revealed the presence of six flavonoids, one triterpenoid, one phytosterol, and one long chain ester. 
Table 1. Peaks assignments using UPLC-ESI/MS/MS of metabolites in Gleditsia caspica extract

\begin{tabular}{|c|c|c|c|c|c|}
\hline $\begin{array}{l}\text { Peak } \\
\text { no. }\end{array}$ & Identified Compound & $\begin{array}{l}\text { Retention } \\
\text { time (min) }\end{array}$ & $\begin{array}{c}\text { Molecular ion } \\
(\mathbf{m} / \mathbf{z})\end{array}$ & $\begin{array}{l}\text { Fragment } \\
\text { ions }(\mathbf{m} / \mathbf{z})\end{array}$ & Reference \\
\hline GC1 & $\begin{array}{l}\text { Kaempferol -O-rhamnosyl } \\
\text { hexoside -O- rhamnoside }\end{array}$ & 7.27 & {$[\mathrm{M}-\mathrm{H}]^{-}$at $m / z 739$} & $\begin{array}{c}448,431,285 \\
119\end{array}$ & [42] \\
\hline $\mathrm{GC} 2$ & Eriodictyol-7-O- hexoside & 8.53 & $\begin{array}{l}{[\mathrm{M}-\mathrm{H}]^{-} \text {at } m / z 449} \\
{[\mathrm{M}+\mathrm{H}]^{+} \text {at } m / z 451}\end{array}$ & $\begin{array}{c}287,289,151 \\
153\end{array}$ & [43] \\
\hline GC3 & Apigenin C-hexoside & 9.28 & $\begin{array}{c}{[\mathrm{M}-\mathrm{H}]^{-} \text {at } m / z 431} \\
{[\mathrm{M}+\mathrm{H}]^{+} \text {at } m / z 433}\end{array}$ & $313,311,283$ & [44] \\
\hline GC4 & $\begin{array}{l}\text { Naringenin-7-O- hexoside- } \\
\text { deoxy-hexoside }\end{array}$ & 9.86 & {$[\mathrm{M}-\mathrm{H}]^{-}$at $m / z 579$} & 271,151 & {$[45,46]$} \\
\hline GC5 & Naringenin-7-O-hexoside & 25.32 & $\begin{array}{c}{[\mathrm{M}+\mathrm{Na}]^{+} \text {at } m / z 457} \\
{[\mathrm{M}+\mathrm{H}]^{+} \text {at } m / z 435}\end{array}$ & 163 & [47] \\
\hline GC6 & Dihydrokeampferol & 11.04 & {$[\mathrm{M}-\mathrm{H}]^{-}$at $m / z 287$} & 151,135 & [48] \\
\hline GC7 & Lupeol & 25.86 & {$[\mathrm{M}+\mathrm{H}]^{+}$at $m / z 427$} & $\begin{array}{c}392,109,94 \\
91,57\end{array}$ & [49] \\
\hline GC8 & Stigmasterol & 26.6 & $\begin{array}{c}{[\mathrm{M}+\mathrm{H}]^{+} \text {of } m / z 413} \\
{\left[\mathrm{M}-\mathrm{H}_{2} \mathrm{O}+\mathrm{H}\right]^{+} \text {at } m / z} \\
395\end{array}$ & 269,215 & {$[50,51]$} \\
\hline GC9 & $\begin{array}{l}\text { 2(R)-26-\{[(2E)-3-(4-hydroxy- } \\
\text { 3-methoxyphenyl)-1-oxo-2- } \\
\text { propen-1-yl]oxy\}t-2,3- } \\
\text { dihydroxypropyl ester }\end{array}$ & 27.83 & {$[\mathrm{M}-\mathrm{H}]^{-}$of $m / z 621$} & 501 & [20] \\
\hline
\end{tabular}

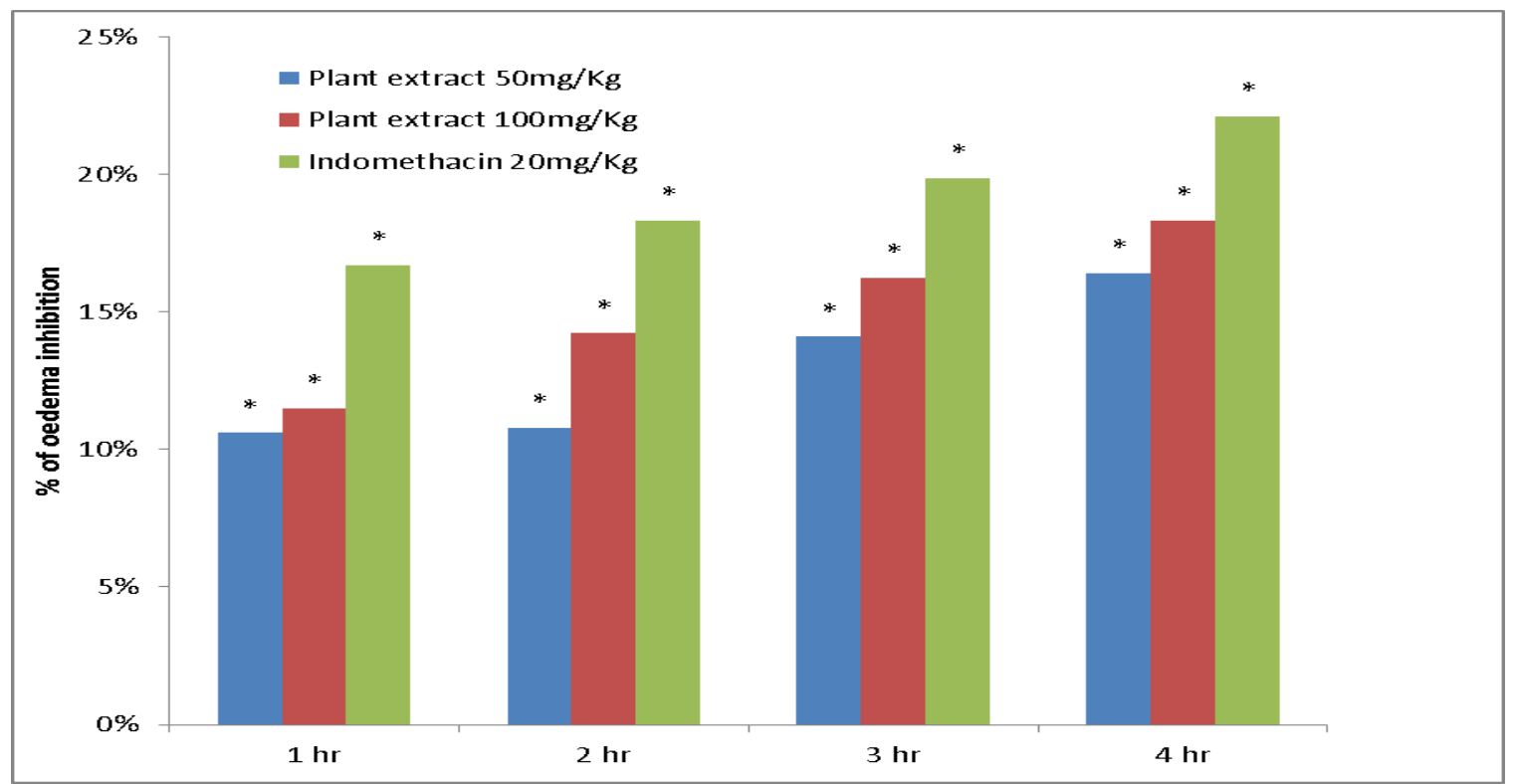

Fig. 1. Effect of Gleditsia caspica extract on rat skin edema thickness in two different doses after 1, 2, 3, and $4 \mathrm{~h}$ of the samples administration. *The difference is significant at $\mathrm{P}<0.05$ 
Table 2. Acute in-vivo anti-inflammatory activity of plant extracts and indomethacin (reference drug) in carrageenan-induced paw edema model

\begin{tabular}{|c|c|c|c|c|c|}
\hline \multirow{3}{*}{ Group } & \multicolumn{5}{|c|}{ Paw diameter (mm) } \\
\hline & Zero time & $1 \mathrm{~h}$ & $2 \mathrm{~h}$ & $3 \mathbf{h}$ & $4 \mathrm{~h}$ \\
\hline & \multicolumn{5}{|c|}{ Edema inhibition (\%) } \\
\hline $\begin{array}{l}\text { Control } \\
\text { (Carrageenan } \\
+1 \mathrm{~mL} \text { saline) }\end{array}$ & $3.46 \pm 0.03$ & $4.61 \pm 0.09 *$ & $4.64 \pm 0.09 *$ & $4.68 \pm 0.1 *$ & $4.75 \pm 0.1 *$ \\
\hline $\begin{array}{l}\text { Plant extract } \\
50 \mathrm{mg} / \mathrm{kg}\end{array}$ & $3.46 \pm 0.07$ & $\begin{array}{c}4.12 \pm 0.1 * \\
10.6 \%\end{array}$ & $\begin{array}{c}4.14 \pm 0.1^{*} \\
10.78 \%\end{array}$ & $\begin{array}{c}4.02 \pm 0.1^{*} \\
14.1 \%\end{array}$ & $\begin{array}{c}3.97 \pm 0.08 * \\
16.42 \%\end{array}$ \\
\hline $\begin{array}{l}\text { Plant extract } \\
100 \mathrm{mg} / \mathrm{kg}\end{array}$ & $3.47 \pm 0.03$ & $\begin{array}{c}4.08 \pm 0.1 * \\
11.5 \%\end{array}$ & $\begin{array}{c}3.98 \pm 0.06^{*} \\
14.22 \%\end{array}$ & $\begin{array}{c}3.92 \pm 0.1 * \\
16.24 \%\end{array}$ & $\begin{array}{c}3.88 \pm 0.07 * \\
18.32 \%\end{array}$ \\
\hline $\begin{array}{l}\text { Indomethacin } \\
20 \mathrm{mg} / \mathrm{kg}\end{array}$ & $3.51 \pm 0.05$ & $\begin{array}{c}3.84 \pm 0.03 * \\
16.7 \%\end{array}$ & $\begin{array}{c}3.79 \pm 0.03 * \\
18.32 \%\end{array}$ & $\begin{array}{c}3.75 \pm 0.04 * \\
19.87 \%\end{array}$ & $\begin{array}{c}3.70 \pm 0.06 * \\
22.11 \%\end{array}$ \\
\hline
\end{tabular}

Data represented as mean \pm SD of six independent experiments. Analysis was done using the one way analysis of variance (ANOVA), followed by post-hoc Tukey's test. *The difference is significant at $\mathrm{P}<0.05$.

\subsection{Evaluation of the in-vivo anti- inflammatory activities}

One of the most frequently used methods to evaluate the anti-inflammatory effects of natural products is Carrageenan-induced paw edema. Carrageenan was injected and induced inflammation in rat hind paw and increased paw diameter to $4.75 \mathrm{~mm}$. Gleditsia caspica extract reduced hind paw inflammation time and dosedependently. Results were summarized in (table 2 and Fig. 1).

\section{DISCUSSION}

In this study, the characterization of the Phyto-constituents of Gleditsia caspica extract using the UPLC-ESI-LC/MS/MS approach was carried out to identify the chemical components within the plant associated with this biological activity. Kaempferol -O-rhamnosyl hexoside -Orhamnoside; reported for the first time from genus Gleditsia was detected in peak (GC1) having its molecular ion $[\mathrm{M}-\mathrm{H}]^{-}$at $\mathrm{m} / \mathrm{z} 739$ with fragments at $m / z \quad 448 \quad[\mathrm{M}-291-\mathrm{H}]^{-}$typical to kaempferol-3-hexoside and $m / z$ 431 [M-308-H] typical to kaempferol-7-deoxy-hexoside with MS/MS fragment ions at $m / z 119$ produced by the retro-Diels-Alder (RDA) cleavage of the $\mathrm{C}$ ring of kaempferol. Such fragments confirmed the presence of kaempferol -O-rhamnosyl hexoside -O- rhamnoside that was previously detected [42]. Peak (GC2) represented the flavonoid eriodictyol-7-O-hexoside; previously isolated from the fruits of the same species [48]. Its parent ion peak $[\mathrm{M}-\mathrm{H}]^{-}$at $\mathrm{m} / z \quad 449$ and $[\mathrm{M}+\mathrm{H}]^{+}$at $\mathrm{m} / z \quad 451$ were obvious; additionally, it has two ion peaks at $\mathrm{m} / \mathrm{z} 287$ and $\mathrm{m} / \mathrm{z} 289$ correspondings to the aglycone part with a molecular mass of $288 \mathrm{Da}$ with MS/MS fragment ions at $m / z, 151$ in the negative mode and m/z 153 in the positive mode corresponding to the characteristic (RDA) cleavage between different chemical bonds of the ring $\mathrm{C}$ [43]. Peak (GC3) was shown to be apigenin flavone glycoside previously isolated from Gleditsia triacanthos as vitexin and iso-vitexin [8]. It revealed molecular ion peaks of $[\mathrm{M}-\mathrm{H}]^{-}$at $\mathrm{m} / z 431$ and $[\mathrm{M}+\mathrm{H}]^{+}$at $\mathrm{m} / \mathrm{z} 433$, in which MS/MS spectrum showed two predominant fragments at $\mathrm{m} / \mathrm{z} 313$ 
correspondings to the glycosyl ring fracture, $\mathrm{m} / \mathrm{z}$ 283 corresponding to the aglycone part and a characteristic fragment at $m / z 311$ [M-H-120] [44]. Peak (GC4) was recognized as naringenin7-O-glycoside (disaccharide derivative); reported for the first time from genus Gleditsia and produced a $[\mathrm{M}-\mathrm{H}]^{-}$at $\mathrm{m} / \mathrm{z} 579$ typical to disaccharide derivatives of naringenin and the MS/MS spectrum showed two characteristic daughter ion peaks for naringenin at $\mathrm{m} / z 271$ and 151 [45, 46]. Furthermore, peak (GC6) was characterized as dihydrokeampferol; previously isolated from Gleditsia sinensis [6] owing to its molecular ion peak $[\mathrm{M}-\mathrm{H}]^{-}$at $\mathrm{m} / z, 287$ and the fragment ions at $m / z 151$ and $m / z$, 135 [48]. Lupeol; detected for the first time from genus Gleditsia was identified at peak (GC7) that produced a $[\mathrm{M}+\mathrm{H}]^{+}$at $\mathrm{m} / \mathrm{z} \quad 427$ and was confirmed by the characteristic fragments at $\mathrm{m} / \mathrm{z}$ $392, \mathrm{~m} / \mathrm{z} 109, \mathrm{~m} / \mathrm{z} 94, \mathrm{~m} / \mathrm{z} 91$ and $\mathrm{m} / \mathrm{z} 57$ as reported previously [49]. Stigmasterol; previously isolated from Gleditsia sinensis was recognized in peak (GC8) by the molecular ion $[\mathrm{M}+\mathrm{H}]^{+}$of $m / z, 413$ with $\left[\mathrm{M}-\mathrm{H}_{2} \mathrm{O}+\mathrm{H}\right]^{+}$at $m / z 395$ [3]. Its MS/MS spectrum showed a fragment ion peak at $m / z 269$ that was attributed to the loss of the side chain with two hydrogen atoms from the steroidal nucleus, which is characteristic to steroids with unsaturated side chain and a characteristic fragment at $m / z 215$ [50, 51]. Naringenin-7- $O$-hexoside; previously isolated from the fruits of Gleditsia caspica [47] has been detected in Gleditsia caspica leaves extract in peak (GC6) that showed a molecular ion peak of $[\mathrm{M}+\mathrm{H}]^{+}$at $\mathrm{m} / z 435$ and $[\mathrm{M}+\mathrm{Na}]^{+}$at $\mathrm{m} / z, 457$ with MS/MS fragment at $m / z 163$ correspondings to the hexose moiety. A newly isolated long-chain ester; 2(R)-26-\{[(2E)-3-(4-hydroxy-3methoxyphenyl)-1-oxo-2-propen-1-yl]oxy \}t-2,3dihydroxy propyl ester [20] was identified as the first report from this species in peak (GC9) with deprotonated molecule $[\mathrm{M}-\mathrm{H}]^{-}$of $\mathrm{m} / \mathrm{z} 621$ and MS/MS fragment at $\mathrm{m} / z 501$ ([M-120]') that could arise from the cleavage of one ester bond.

This study was also conducted to evaluate the in-vivo anti-inflammatory activity of Gleditsia caspica extract. As aforementioned, the carrageenan-induced paw edema model is one of the major models used in the assessment of the anti-inflammatory effects of natural products. After one hour of Gleditsia caspica administration, there wasn't a marked reduction in the rat hind paw edema compared to the reference group. During the follow-up period, an increase in the percentage of the edema inhibition was noticed. Paw diameter reduction was increased by increasing the dose from $50 \mathrm{mg} / \mathrm{kg}$ to $100 \mathrm{mg} / \mathrm{kg}$, and the effect of the extract at 100 $\mathrm{mg} / \mathrm{kg}$ dose was comparable to that of the reference drug indomethacin. The reduction in paw diameter recorded $18.32 \%$ and $22.11 \%$ for the extract $(100 \mathrm{mg} / \mathrm{kg})$ and reference drug (indomethacin), respectively, after four hours of carrageenan administration. Accordingly, it could be concluded that the hydro-alcoholic extract of Gleditsia caspica exhibited time and dosedependent anti-inflammatory activity. Flavonoids are key constituents involved in the antiinflammatory activities within the plants. In this study, six flavonoids were tentatively identified within Gleditsia caspica extract. Biological investigations have reported different antiinflammatory mechanisms of eriodictyol [52], apigenin [53], kaempferol [54], and naringenin [55] and their glycosides. It could be concluded that Gleditsia caspica extract is a potential bioactive candidate that could be incorporated in topical anti-inflammatory preparations owing to its flavonoids components.

\section{CONCLUSION}

UPLC-ESI/MS/MS analysis of Gleditsia caspica extract revealed its richness in flavonoids, newly reported compounds from this genus, and from this species. Antiinflammatory assays revealed that the hydro-alcoholic extract 
of Gleditsia caspica possessed dose and time dependant activity. These results suggested the possible use of Gleditsia caspica extract in topical anti-inflammatory preparations with minimal side effects.

\section{DECLARATIONS}

\section{Ethics approval and consent to participate}

The protocol of the experiment was approved by the Institutional Animal Ethical Committee in the National Research Center (registration no. 90123) [40].

\section{Consent to publish}

Not applicable.

\section{Availability of data and materials}

All data generated or analyzed during this study were included in the main manuscript.

\section{Competing interests}

The authors declare that no competing interests exist.

\section{Funding Statement}

No funding source was received.

\section{Authors' contributions}

The manuscript was drafted and written by Hagar Ashraf. Dr. Ashaimaa Y. Moussa, Prof. Omayma A. Eldahshan, and Prof. Abdel Nasser B. Singab have provided comments and revised the manuscript. All authors have read and approved the final manuscript.

\section{Acknowledgment}

The authors would like to acknowledge all colleagues in the Pharmacognosy Department; Ain shams University for their support.

\section{LIST OF ABBREVIATIONS}

UPLC, Ultra performance liquid chromatography; ESI, Electrospray ionization; MS, Mass spectrometry; eV, Electron volt; kV,
Kilovolt; L/h, Liter per hour; Rt, Retention time; ANOVA, Analysis of variance.

\section{REFERENCES}

1. Zhang J.-P., Tian X.-H., Yang Y.-X., Liu Q.X., Wang Q., Chen L.-P., et al. Gleditsia species: an ethnomedical, phytochemical, and pharmacological review. Journal Of Ethnopharmacology 2016; 178: 155-71 DOI: https://doi.org/10.1016/j.jep.2015.11.044.

2. Huxley A, Griffiths M, Levy M, Dictionary of gardening: the new royal horticultural society. Vol. 2. London: Macmillan;1992.

3. Lim J.-C., Park J.H., Budesinsky M., Kasal A., Han Y.-H., Koo B.-S., et al. Antimutagenic constituents from the thorns of Gleditsia sinensis. Chemical And Pharmaceutical Bulletin 2005; 53: 561-64 DOI: https://doi.org/10.1248/cpb.53.561.

4. Zhang Z., Koike K., Jia Z., Nikaido T., Guo D., and Zheng J. Triterpenoidal saponins from Gleditsia sinensis. Phytochemistry 1999; 52: $\quad 715-22 \quad$ DOI: https://doi.org/10.1016/S00319422(99)00238-1.

5. Li W.-H., Zhang X.-M., Tian R.-R., Zheng Y.-T., Zhao W.-M., and Qiu M.-H. A new anti-HIV lupane acid from Gleditsia sinensis Lam. Journal Of Asian Natural Products Research 2007; 9: 551-55 DOI: https://doi.org/10.1080/10286020600883419.

6. Zhou L., Li D., Wang J., Liu Y., and Wu J. Antibacterial phenolic compounds from the spines of Gleditsia sinensis Lam. Natural Product Research 2007; 21: 283-91 DOI: https://doi.org/10.1080/14786410701192637.

7. Zhou L., Li D., Jiang W., Qin Z., Zhao S., Qiu M., et al. Two ellagic acid glycosides from Gleditsia sinensis Lam. with antifungal activity on Magnaporthe grisea. Natural Product Research 2007; 21: 303-09 DOI: 
https://doi.org/10.1080/14786410701192702.

8. Mohammed R., Zeid A.A., El Hawary S., Sleem A., and Ashour W. Flavonoid constituents, cytotoxic and antioxidant activities of Gleditsia triacanthos L. leaves. Saudi Journal of Biological Sciences 2014; 21:

DOIhttps://doi.org/10.1248/bpb.b13-00318.

9. Kajimoto T., Aoki N., Ohta E., Kawai Y., and Ohta S. Saikachinoside A, a novel 3prenylated isoguanine glucoside from seeds of Gleditsia japonica. Tetrahedron Letters 2010; 51: 2099-101 DOI: https://doi.org/10.1016/j.tetlet.2010.01.090.

10. 10. Konoshima T., Yasuda I., Kashiwada Y., Cosentino L.M., and Lee K.-H. Anti-AIDS agents, 21. Triterpenoid saponins as anti-HIV principles from fruits of Gleditsia japonica and Gymnocladus chinesis, and a structureactivity correlation. Journal Of Natural Products 1995; 58: 1372-77.

11. Zhang Z., Koike K., Jia Z., NIKAIDO T., GUO D., and ZHENG J. Triterpenoidal saponins acylated with two monoterpenic acids from Gleditsia sinensis. Chemical And Pharmaceutical Bulletin 1999; 47: 388-93 DOI: https://doi.org/10.1248/cpb.47.388.

12. Duchenko M., Demeshko O., and Kovalev V. Flavonoids from Gleditsia triacanthos. Chemistry Of Natural Compounds 2016; 52: 1093-94

DOI: https://doi.org/10.1016/j.sjbs.2014.02.002.

13. Belikov A., Ban'kovskii A., and Tsarev M. Alkaloid from Gleditschia triacanthos. Zhur. Obsch. Khim. 1954; 24: 919-22 DOI: https://doi.org/10.1007/s10600-016-1870-6.

14. Miyase T., Melek F., Warashina T., Selim M., El Fiki N., and Kassem I. Cytotoxic triterpenoid saponins acylated with monoterpenic acids from fruits of Gleditsia caspica Desf. Phytochemistry 2010; 71: 1908-16.

15. Melek F., Kassem I., Miyase T., and Fayad W. Caspicaosides E-K, triterpenoid saponins and cytotoxic acylated saponins from fruits of Gleditsia caspica Desf. Phytochemistry 2014; $\quad 100$ : $110-19$ DOI: https://doi.org/10.1016/j.phytochem.2010.08. $\underline{001 .}$.

16. Shaheen U., Ragab E.A., Abdalla A.N., and Bader A. Triterpenoidal saponins from the fruits of Gleditsia caspica with proapoptotic properties. Phytochemistry 2018; 145: 16878

DOI: https://doi.org/10.1016/j.phytochem.2014.01. $\underline{019}$.

17. Melek F.R., Aly F.A., Kassem I.A., AboZeid M.A., Farghaly A.A., and Hassan Z.M. Three further triterpenoid saponins from Gleditsia caspica fruits and protective effect of the total saponin fraction on cyclophosphamide-induced genotoxicity in mice. Zeitschrift Für Naturforschung C 2015; 70: $\quad 31-37 \quad$ DOI: https://doi.org/10.1016/j.phytochem.2017.11. 007.

18. Ha H.H., Park S.Y., Ko W.S., and Kim Y. Gleditsia sinensis thorns inhibit the production of NO through NF- $\kappa \mathrm{B}$ suppression in LPS-stimulated macrophages. Journal Of Ethnopharmacology 2008; 118: 429-34 DOI: https://doi.org/10.1515/znc2014-4132.

19. YIN W.-p., LIU H.-q., GAO J.-y., and CAO R.-r. Investigation of three coumarin components in thorns of Gleditsia sinensis and their cytotoxic activity to tumor cells. Chinese Traditional And Herbal Drugs 2016; 2016: $\quad 10 \quad$ DOI: https://doi.org/10.1016/j.jep.2008.05.004. 
20. Yu J.-Q., Xian Y.-X., Geng Y.-L., Wang D.J., Zhou H.-L., and Wang X. Anti-liver cancer constituents from the thorns of Gleditsia sinensis. Phytochemistry Letters 2015; 13 : $\quad 343-47$ DOI: https://doi.org/10.1016/j.phytol.2015.07.018.

21. Yu J., Li G., Mu Y., Zhou H., Wang X., and Yang P. anti-breast cancer triterpenoid saponins from the thorns of Gleditsia sinensis. Natural Product Research 2019; 33: 2308-13

DOI: https://doi.org/10.1080/14786419.2018.1443 092.

22. Dai Y., Chan Y.-P., Chu L.-M., and But P.P.H. Antiallergic and anti-inflammatory properties of the ethanolic extract from Gleditsia sinensis. Biological And Pharmaceutical Bulletin 2002; 25: 1179-82 DOI: https://doi.org/10.1248/bpb.25.1179.

23. Fu L.-J., Dai Y., Wang Z.-T., and Zhang M. Inhibition of experimental allergic rhinitis by the n-butanol fraction from the anomalous fruits of Gleditsia sinensis. Biological And Pharmaceutical Bulletin 2003; 26: 974-77 DOI: https://doi.org/10.1248/bpb.26.974.

24. Lai P., Liu Y. Echinocystic acid, isolated from Gleditsia sinensis fruit, protects endothelial progenitor cells from damage caused by oxLDL via the Akt/eNOS pathway. Life Sciences 2014; 114: 62-69 DOI: https://doi.org/10.1016/j.lfs.2014.07.026.

25. 25. Saleh D.O., Kassem I., and Melek F.R. Analgesic activity of Gleditsia triacanthos methanolic fruit extract and its saponincontaining fraction. Pharmaceutical Biology 2016; 54: 576-80 DOI: https://doi.org/10.3109/13880209.2015.1064 $\underline{450}$.

26. Ragab E.A. New antimicrobial and cytotoxic acylated triterpenoidal saponins from
Gleditsia aquatica. Medicinal Chemistry Research 2015; 24: 2916-25 DOI: https://doi.org/10.1007/s00044-015-1345-5.

27. Choi J.-Y., Kwun M.J., Kim K.H., Lyu J.H., Han C.W., Jeong H.-S., et al. Protective effect of the fruit hull of Gleditsia sinensis on LPS-induced acute lung injury is associated with Nrf2 activation. Evidence-Based Complementary And Alternative Medicine 2012; 2012: DOI: https://doi.org/10.1155/2012/974713.

28. Kim K.H., Kwun M.J., Han C.W., Ha K.-T., Choi J.-Y., and Joo M. Suppression of lung inflammation in an LPS-induced acute lung injury model by the fruit hull of Gleditsia sinensis. BMC Complementary And Alternative Medicine 2014; 14: 402 DOI: https://doi.org/10.1186/1472-6882-14-402.

29. Sultana N., Saeed Saify Z. Naturally occurring and synthetic agents as potential anti-inflammatory and immunomodulators. Anti-Inflammatory \& Anti-Allergy Agents in Medicinal Chemistry (Formerly Current Medicinal Chemistry-Anti-Inflammatory and Anti-Allergy Agents) 2012; 11: 3-19 DOI: https://doi.org/10.2174/18715231280347626 4.

30. Domenjoz R., Synthetic anti-inflammatory drugs: Concepts of their mode of action, in Advances in pharmacology. Elsevier 1966; 4:143-217 DOI: https://doi.org/10.1016/S10543589(08)60099-X.

31. Ophaswongse S., Maibach H. Topical nonsteroidal antiinflammatory drugs: allergic and photoallergic contact dermatitis and phototoxicity. Contact Dermatitis 1993; 29: 57-64 DOI: https://doi.org/10.1111/j.16000536.1993.tb03483.x.

32. Figueiredo A., Fontes C., Gonçalo S., Caladeira M., Poiares-Baptista A., and 
Teixeira $\quad$ F. Piroxicam-induced photosensitivity. Contact Dermatitis 1987; 17: $\quad$ 73-79 DOI: https://doi.org/10.1111/j.16000536.1987.tb02664.x.

33. Pigatto P., Riboldi A., Morelli M., Altomare G., and Polenghi M. Allergic contact dermatitis from oxyphenbutazone. Contact Dermatitis 1985; 12: 236-37 DOI: 10.1111/j.1600-0536.1985.tb01126.x.

34. Kraft M., Soost S., and Worm M. Topical and Systemic Corticosteroids. Kanerva's Occupational Dermatology 2020; 1433-44 DOI: https://doi.org/10.1007/978-3-31968617-2_92.

35. Molin S.C., Ruzicka T. Retinoids. Kanerva's Occupational Dermatology 2020; 1417-31.

36. El-Ghaffar E.A.A., Al-Sayed E., Shehata S.M., Eldahshan O.A., and Efferth T. The protective role of Ocimum basilicum L.(Basil) against aspirin-induced gastric ulcer in mice: Impact on oxidative stress, inflammation, motor deficits, and anxietylike behavior. Food \& Function 2018; 9: 4457-68 DOI: 10.1039/C8FO00538A.

37. El-Ghaffar E.A.A., Eldahshan O.A., Barakat A., and Efferth T. The prophylactic effect of a Eugenia aquea extract against oxidative stress and inflammation associated with the development of arthritis in an adjuvantinduced arthritis rat model. Food \& Function 2018; $\quad 9: \quad 6643-51 \quad$ DOI: 10.1039/C8FO01570H.

38. Azab S.S., Abdel Jaleel G.A., and Eldahshan O.A. Anti-inflammatory and gastroprotective potential of leaf essential oil of Cinnamomum glanduliferum in ethanolinduced rat experimental gastritis. Pharmaceutical Biology 2017; 55: 1654-61 DOI: https://doi.org/10.1080/13880209.2017.1314

$\underline{512}$.

39. Winter C.A., Risley E.A., and Nuss G.W. Carrageenin-induced edema in hind paw of the rat as an assay for anti-inflammatory drugs. Proceedings Of The Society For Experimental biology And Medicine 1962; 111: 544-47 DOI: https://doi.org/10.3181/00379727-111$\underline{27849}$.

40. Ibrahim A.Y., El-Gengaihi S.E., Motawea H.M., and SLEEM A.A. Anti-inflammatory activity of Salvadora persica L. against carrageenan-induced paw edema in rat relevant to inflammatory cytokines. Notulae Scientia Biologicae 2011; 3: 22-28 DOI: https://doi.org/10.15835/nsb346378.

41. Hajhashemi V., Ghannadi A., and Sharif B. Anti-inflammatory and analgesic properties of the leaf extracts and essential oil of Lavandula angustifolia Mill. Journal Of Ethnopharmacology 2003; 89: 67-71 DOI: https://doi.org/10.1016/S03788741(03)00234-4.

42. Tsukaya H., Sawada Y., Oikawa A., Shiratake K., Isuzugawa K., Saito K., et al. Intraspecific comparative analyses of metabolites between diploid and tetraploid Arabidopsis thaliana and Pyrus communis. New Negatives In Plant Science 2015; 1: 53 61

DOI: https://doi.org/10.1016/j.neps.2015.06.001.

43. Es-Safi N.-E., Kerhoas L., Einhorn J., and Ducrot P.-H. Application of ESI/MS, CID/MS and tandem MS/MS to the fragmentation study of eriodictyol 7-Oglucosyl- $(1 \rightarrow 2)$-glucoside and luteolin $7-\mathrm{O}$ glucosyl-( $\rightarrow$ 2)-glucoside. International Journal Of Mass Spectrometry 2005; 247: 93-100

DOI: https://doi.org/10.1016/j.ijms.2005.10.002. 
44. Li K., Gao C., and Li W. Study on fragmentation of vitexin and isorhamnetin-3o-beta-D-rutinoside using electrospray quadrupole time of flight mass spectrometry. China Journal Of Chinese Materia Medica 2011; 36: 180-84.

45. Zhang M., Duan C., Zang Y., Huang Z., and Liu $\mathrm{G}$. The flavonoid composition of flavedo and juice from the pummelo cultivar (Citrus grandis (L.) Osbeck) and the grapefruit cultivar (Citrus paradisi) from China. Food Chemistry 2011; 129: 1530-36 DOI: https://doi.org/10.1016/j.foodchem.2011.05.1 $\underline{36}$.

46. Lee S., Khoo C.S., Pearson J.L., Hennell J.R., and Bensoussan A. Liquid chromatographic determination of narirutin and hesperidin in Zhi Ke (Citrus aurantium L.) in the form of the raw herb and the dried aqueous extract. Journal Of AOAC International 2009; 92: 789-96.

47. Reed K.A. Identification of phenolic compounds from peanut skin using HPLCMSn. Virginia Tech2009

48. Ragab E.A., Hosny M., Kadry H.A., and Ammar H.A. Flavanone glycosides from Gleditsia caspia. Journal Of Natural Products 2010; 3: 35-46.

49. Doshi G.M., Nalawade V.V., Mukadam A.S., Chaskar P.K., Zine S.P., Somani R.R., et al. Structural elucidation of chemical constituents from Benincasa hispida seeds and Carissa congesta roots by gas chromatography: Mass spectroscopy. Pharmacognosy Research 2015; 7: 282 DOI: 10.4103/0974-8490.157179.

50. Blekas G., Boskou D. Oxidation of stigmasterol in heated triacylglycerols. Food Chemistry 1989; 33: 301-10 DOI: https://doi.org/10.1016/0308-8146(89)90040$\underline{X}$.
51. Münger L.H., Boulos S., and Nyström L. UPLC-MS/MS-based identification of dietary steryl glucosides by investigation of corresponding free sterols. Frontiers In Chemistry 2018; 6: 342 DOI: https://doi.org/10.3389/fchem.2018.00342.

52. Wang Y., Chen Y., Chen Y., Zhou B., Shan X., and Yang G. Eriodictyol inhibits IL-1 $\beta$ induced inflammatory response in human osteoarthritis chondrocytes. Biomedicine \& Pharmacotherapy 2018; 107: 1128-34 DOI: https://doi.org/10.1016/j.biopha.2018.08.103.

53. Karamese M., Erol H.S., Albayrak M., Findik Guvendi G., Aydin E., and Aksak Karamese S. Anti-oxidant and antiinflammatory effects of apigenin in a rat model of sepsis: an immunological, biochemical, and histopathological study. Immunopharmacology And Immunotoxicology 2016; 38: 228-37 DOI: https://doi.org/10.3109/08923973.2016.1173 $\underline{058}$.

54. Wang J., Fang X., Ge L., Cao F., Zhao L., Wang Z., et al. Antitumor, antioxidant, and anti-inflammatory activities of kaempferol and its corresponding glycosides and the enzymatic preparation of kaempferol. PLoS One 2018; 13: DOI: 10.1371/journal.pone.0197563.

55. Pinho-Ribeiro F.A., Zarpelon A.C., Fattori V., Manchope M.F., Mizokami S.S., Casagrande R., et al. Naringenin reduces inflammatory pain in mice. Neuropharmacology 2016; 105: 508-19 DOI: https://doi.org/10.1016/j.neuropharm.2016.02 .019 . 